\title{
GAMBARAN KEMAMPUAN KONSENTRASI MAHASISWA PROGRAM STUDI KEDOKTERAN FAKULTAS KEDOKTERAN UNIVERSITAS MALIKUSSALEH
}

\author{
Cut Sidrah Nadira ${ }^{1}$ Cut Khairunnisa ${ }^{2}$ \\ ${ }^{1}$ Bagian Fisiologi, Fakultas Kedokteran, Universitas Malikussaleh, Lhokseumawe, Indonesia \\ ${ }^{2}$ Bagian Kesehatan Masyarakat, Fakultas Kedokteran, Universitas Malikussaleh, Lhokseumawe, Indonesia \\ Corresponding author: sidrahnadira@gmail.com
}

\begin{abstract}
Abstrak
Mahasiswa kedokteran memiliki jadwal kegiatan yang cukup padat dan tugas yang banyak sehingga untuk menyelesaikannya dibutuhkan organisasi waktu dan pekerjaan yang baik. Tak jarang tugas-tugas tersebut dikerjakan bersamaan dengan pekerjaan lainnya. Menyelesaikan banyak pekerjaan dalam satu waktu cenderung menyebabkan lebih banyak distraktor yang diolah oleh otak. Untuk mempertahankan performa seseorang dalam melakukan pekerjaan tersebut dibutuhkan konsentrasi yang baik sehingga distraksi yang banyak dapat diminimalkan. Penelitian ini bertujuan untuk mengetahui gambaran tingkat konsentrasi yang dimiliki oleh mahasiswa Program Studi Kedokteran Universitas Malikussaleh. Penelitian yang dilaksanakan di Program Studi Kedokteran Fakultas Kedokteran Universitas Malikussaleh ini merupakan penelitian deskriptif dengan menggunakan pendekatan cross sectional. Sampel yang memenuhi kriteria inklusi dan eksklusi sebanyak 38 orang diperoleh dengan metode convenience sampling. Identifikasi kemampuan konsentrasi mahasiswa ini dilakukan menggunakan metode Digit Span Test Forward \& Backward, selanjutnya data yang diperoleh dianalisis secara univariat. Hasil penelitian menunjukkan rerata nilai untuk digit span forward yang didapatkan adalah $6,95 \pm 1,39$ dengan skor median 7 ; dan untuk digit

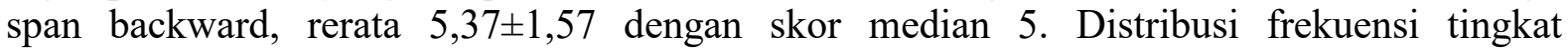
konsentrasi sebagian besar responden di atas skor 7 untuk digit span forward $(68,42 \%)$ dan di atas skor 5 untuk digit span backward (71,05\%). Hasil ini menunjukkan gambaran kemampuan konsentrasi yang dimiliki oleh mahasiswa Program Studi Kedokteran Universitas Malikussaleh memiliki nilai yang cukup baik (berada di atas atau sama dengan nilai median).
\end{abstract}

Kata kunci: konsentrasi; digit span test; backward; forward

\section{Overview of Students Concentration Ability in Universitas Malikussaleh Doctor of Medicine Program}

\begin{abstract}
The students of Doctor of Medicine (M.D.) Program have hectic schedule and many tasks to do which need good organization of time and tasks. These tasks are often done simultaneously. Completing many tasks in one time tends to cause more distractors processed by the brain. Mantaining the performance in completing tasks needs good concentration so can minimalize the distractions. This research aim to know the overview of students concentration ability in Universitas Malikussaleh Doctor of Medicine Program. This research is a descriptive study using cross sectional approach. Thirty eight samples that met inclusion and exclusion criteria was obtained by convenience sampling method. Students concentration
\end{abstract}


ability was identified by Forward and Backward Digit Span Test. The data is then analized univariately. The result showed that the mean value for digit span forward was $6,95 \pm 1,39$

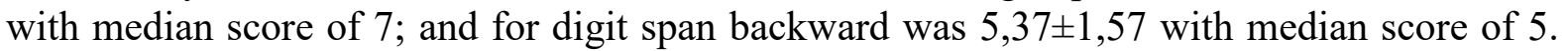
Most of respondents have score above 7 for digit span forward $(68,42 \%)$ and above 5 for digit span backward (71,05\%). These results mean that Universitas Malikussaleh Doctor of Medicine Program's students have an adequate value for concentration ability (above or equal to median value).

Keywords: backward;concentration; digit span test; forward

\section{PENDAHULUAN}

Seseorang yang sedang berhadapan dengan suatu pekerjaan yang menantang atau menarik perhatiannya cenderung akan mengabaikan apa yang sedang terjadi di lingkungan sekitarnya. Situasi ini terjadi sebagai efek dari konsentrasi. Konsentrasi dapat diartikan sebagai usaha memusatkan pikiran untuk menghadapi suatu pekerjaan dengan kesulitan yang tinggi. Konsentrasi akan mengikat seseorang dengan pekerjaannya dengan tujuan mempertahankan performa dalam melakukan pekerjaan tersebut. Akibatnya respon terhadap stimulus dari lingkungan sekitar akan menurun dan terhindar dari distraksi. Kebutuhan untuk berkonsentrasi terutama ditentukan oleh tingkat kesulitan dari suatu pekerjaan, akan tetapi terkadang dapat juga dipengaruhi oleh motivasi dan minat seseorang. ${ }^{1}$

Kemampuan berkonsentrasi terhadap suatu aktivitas memiliki sejumlah implikasi dalam hidup seseorang. Sebagai contoh, karyawan tidak dapat menjadi produktif jika mereka gagal untuk fokus terhadap pekerjaan mereka. Begitu juga pelajar tidak dapat memperoleh nilai yang lebih baik jika mereka seringkali terdistraksi disaat gurunya mengajar. Jangka waktu mempertahankan atensi pada manusia bervariasi tergantung tipe atensinya (atensi berkelanjutan atau sementara). Atensi sementara terjadi ketika stimulus yang biasanya merusak atensi menyebabkan respon singkat. Sebaliknya atensi berkelanjutan terjadi ketika seseorang mempertahankan konsentrasi untuk jangka waktu yang lama. ${ }^{2}$

Mahasiswa Kedokteran diketahui memiliki jadwal kegiatan yang padat dan tugas yang cukup banyak sehingga dibutuhkan organisasi waktu dan pekerjaan yang baik. Tak jarang tugas-tugas tersebut dikerjakan bersamaan dengan pekerjaan lainnya. Beban pikiran yang banyak (misal harus mengerjakan banyak pekerjaan dalam satu waktu) menyebabkan informasi distraktor dari lingkungan sekitar akan lebih banyak diolah oleh otak. ${ }^{3}$ Hal ini akan menyebabkan modalitas yang seharusnya dibutuhkan untuk menyelesaikan pekerjaan tersebut menjadi terpakai, akibatnya kerentanan terhadap distraksi akan meningkat. Untuk 
menghadapi distraksi akibat beban pikiran yang banyak tersebut diperlukan memori kerja dan executive resource yang baik. ${ }^{4}$

Digit Span Test Forward dan Backward. Pada Digit Span Test ini, pasien diberikan serangkaian digit angka secara verbal yang harus mereka ulangi segera setelah diberikan dengan ritme yang sama. Panjang rangkaian angka akan terus bertambah dan skor akhir adalah rangkaian angka terpanjang yang berhasil diulangi dengan benar. Hasil ini dianggap sebagai ukuran kapasitas penyimpanan memori jangka pendek. Pada versi backward, pasien diminta untuk mengulangi rangkaian angka yang disebutkan dengan urutan terbalik. ${ }^{5}$ Digit Span Test versi Forward menilai pemeliharaan jangka pendek dari informasi verbal dan visuospasial tanpa membutuhkan manipulasi lebih lanjut dari data yang disimpan. Proses ini diduga cukup dikelola oleh Slave System tanpa atau sangat sedikit peran Central Executive. Versi Backward tidak hanya memerlukan pemeliharaan data tetapi juga memanipulasinya secara mental untuk memperoleh hasil pengulangan secara terbalik dengan urutan yang benar. Fungsi ini memerlukan lebih banyak peran Central Executive. ${ }^{5}$

\section{METODE}

Penelitian yang dilaksanakan di Program Studi Kedokteran Fakultas Kedokteran Universitas Malikussaleh ini merupakan penelitian deskriptif dengan menggunakan pendekatan cross sectional. Sampel yang memenuhi kriteria inklusi dan eksklusi sebanyak 38 orang diperoleh dengan metode convenience sampling. Identifikasi kemampuan konsentrasi mahasiswa ini dilakukan menggunakan metode Digit Span Test Forward \& Backward, selanjutnya data yang diperoleh dianalisis secara univariat.

\section{HASIL}

Responden yang memenuhi kriteria inklusi dan eksklusi sebanyak 38 orang yang terdiri dari 9 orang laki-laki dan 29 orang perempuan dengan karakteristik usia seperti yang tampak pada tabel 1 .

Tabel 1 Karakteristik usia dan jenis kelamin responden

\begin{tabular}{lll}
\hline Karakteristik Responden & n & \% \\
\hline$\bullet \quad$ Usia & & 26.32 \\
19 Tahun & 10 & 44.74 \\
20 Tahun & 17 & 26.32 \\
21 Tahun & 10 & 2.63 \\
\hline 22 Tahun & 1 & $\mathbf{1 0 0}$ \\
\hline Total Jenis Kelamin & $\mathbf{3 8}$ &
\end{tabular}




\begin{tabular}{lllc} 
& Laki-laki & 9 & 23.68 \\
& Perempuan & 29 & 76.32 \\
\hline Total & $\mathbf{3 8}$ & $\mathbf{1 0 0}$ \\
\hline
\end{tabular}

Tabel tersebut memperlihatkan bahwa $44,74 \%$ responden berusia 20 tahun, masingmasing 26,32\% responden berusia 19 dan 21 tahun dan hanya 2,63\% yang berusia 22 tahun.

Gambaran tingkat konsentrasi responden yang diperoleh dengan menggunakan Digit span test dapat terlihat pada tabel 2 dan 3.

Tabel 2. Hasil Digit span test forward

\begin{tabular}{ccc}
\hline Skor & \multicolumn{2}{c}{ Digit Span Test Forward } \\
\cline { 2 - 3 } & $\mathbf{N}$ & $\mathbf{( \% )}$ \\
\hline Skor 9 & 5 & 13,16 \\
Skor 8 & 9 & 23,68 \\
Skor 7 & 12 & 31,58 \\
Skor 6 & 5 & 13,16 \\
Skor 5 & 5 & 13,16 \\
Skor 4 & 2 & 5,26 \\
Skor 3 & 0 & 0 \\
\hline Total & $\mathbf{3 8}$ & $\mathbf{1 0 0}$ \\
\hline
\end{tabular}

Tabel hasil Digit span test forward menunjukkan bahwa skor terbanyak yang diperoleh oleh responden adalah skor 7 yaitu sebesar $31,58 \%$, diikuti oleh skor 8 yaitu sebesar 23,68\%, dan persentase yang sama masing-masing untuk skor 9, 6 dan 5 yaitu 13,16\%. Hanya 5,26\% yang memperoleh skor 4 dan tidak ada $(0 \%)$ yang memperoleh skor 3. Rerata skor untuk Digit span test forward adalah 6,95.

Tabel 3. Hasil Digit span test Backward

\begin{tabular}{ccc}
\hline Skor & \multicolumn{2}{c}{ Digit Span Test Backward } \\
\cline { 2 - 3 } & $\mathbf{N}$ & $\mathbf{( \% )}$ \\
\hline Skor 8 & 3 & 7,89 \\
Skor 7 & 8 & 21,05 \\
Skor 6 & 6 & 15,79 \\
Skor 5 & 10 & 26,32 \\
Skor 4 & 6 & 15,79 \\
Skor 3 & 4 & 10,53 \\
Skor 2 & 1 & 2,63 \\
\hline Total & $\mathbf{3 8}$ & $\mathbf{1 0 0}$ \\
\hline
\end{tabular}

Tabel hasil Digit span test backward menunjukkan bahwa skor terbanyak yang diperoleh oleh responden adalah skor 5 yaitu 26,32\%, diikuti oleh skor 7 yaitu 21,05\%, skor 6 dan 4 masing- 
masing 15,79\%, skor 3 sebesar 10,53\%, terakhir skor 8 dan skor 2 masing-masing sebesar 7,89 \% dan 2,63\%. Rerata skor untuk Digit span test backward adalah 5,37.

Tabel 4 menunjukkan distribusi frekuensi Skor Digit Span Test Forward berdasarkan Usia Responden. Tabel tersebut memperlihatkan bahwa tidak ada yang memperoleh skor 3 baik pada usia 19, 20, 21, maupun 22. Sebanyak 30\% dari total 10 responden yang berusia 19 tahun memperoleh skor 7; 20\% untuk masing-masing skor 5,6,8 dan 9; dan 10\% untuk skor 6. Untuk usia 20 tahun, dari total 17 responden, paling banyak memperoleh skor 7 yaitu sebesar $35,3 \%$, diikuti oleh skor 8 sebesar $23,5 \%$, selanjutnya skor 4,5 , dan 6 yaitu masingmasing sebesar $11,8 \%$ dan terakhir skor 9 yaitu sebesar 5,9\%. Untuk usia 21, dari total 10 responden, sebanyak masing-masing 30\% memperoleh skor 7 dan $8 ; 20 \%$ memperoleh skor 6; masing-masing 10\% memperoleh skor 5 dan 9; dan tidak ada yang memperoleh skor 3 maupun 4. Responden yang berusia 22 tahun hanya 1 orang dan memperoleh skor 9 (100\%).

Hasil Digit Span Test Backward berdasarkan usia responden dapat dilihat pada tabel 5. Sebanyak masing-masing $20 \%$ dari total 10 responden yang berusia 19 tahun memperoleh skor 3, 4, 6 dan 7; 10\% untuk masing-masing skor 5 dan 8; serta tidak ada yang memperoleh skor 2. Untuk usia 20 tahun, dari total 17 responden, paling banyak memperoleh skor 5 yaitu sebesar 41,2\%, diikuti oleh skor 7 sebesar 17,6\%; selanjutnya skor 3, 4 dan 6 yaitu masingmasing sebesar 11,8\%; skor 2 yaitu sebesar 5,9\%; dan tidak ada yang memperoleh skor 8 (0\%). Untuk usia 21, dari total 10 responden, sebanyak masing-masing 20\% memperoleh skor 4, 5, 6, 7 dan 8; dan tidak ada yang memperoleh skor 2 maupun 3. Responden yang berusia 22 tahun hanya 1 orang dan memperoleh skor 7 (100\%).

Tabel 4 Distribusi Frekuensi Skor Digit Span Test Forward berdasarkan Usia Responden

\begin{tabular}{ccccccccc}
\hline \multirow{2}{*}{$\begin{array}{c}\text { Usia } \\
\text { (tahun) }\end{array}$} & $\mathbf{9}$ & \multicolumn{9}{c}{ Skor Digit Span Test Forward } & \multicolumn{2}{c}{ Total } \\
\cline { 2 - 8 } 1 & $\mathbf{3}$ & $\mathbf{4}$ & $\mathbf{5}$ & $\mathbf{6}$ & $\mathbf{7}$ & $\mathbf{8}$ & $\mathbf{9}$ & 10 \\
& 0 & 0 & 2 & 1 & 3 & 2 & $2(20 \%)$ & $(100 \%)$ \\
\hline \multirow{2}{*}{20} & $(0 \%)$ & $(0 \%)$ & $(20 \%)$ & $(10 \%)$ & $(30 \%)$ & $(20 \%)$ & & 17 \\
& 0 & $2(11,8 \%)$ & $2(11,8 \%)$ & $2(11,8 \%)$ & 6 & $4(23,5 \%)$ & $1(5,9 \%)$ & $(100 \%)$ \\
\hline \multirow{2}{*}{21} & 0 & 0 & 1 & 2 & 3 & 3 & $1(10 \%)$ & 10 \\
& $(0 \%)$ & $(0 \%)$ & $(20 \%)$ & $(20 \%)$ & $(30 \%)$ & $(30 \%)$ & & $(100 \%)$ \\
\hline \multirow{2}{*}{22} & 0 & 0 & 0 & 0 & 0 & 0 & 1 & $1(100 \%)$ \\
& $(0 \%)$ & $(0 \%)$ & $(0 \%)$ & $(0 \%)$ & $(0 \%)$ & $(0 \%)$ & $(100 \%)$ & \\
\hline
\end{tabular}

Tabel 5 Distribusi Frekuensi Skor Digit Span Test Backward Berdasarkan Usia Responden

\begin{tabular}{|c|c|c|c|c|c|c|c|c|}
\hline \multirow{2}{*}{$\begin{array}{c}\text { Usia } \\
\text { (tahun) }\end{array}$} & \multicolumn{7}{|c|}{ Skor Digit Span Test Backward } & \multirow[t]{2}{*}{ Total } \\
\hline & 2 & 3 & 4 & 5 & 6 & 7 & 8 & \\
\hline 19 & $\begin{array}{c}0 \\
(0 \%)\end{array}$ & $\begin{array}{c}2 \\
(20 \%)\end{array}$ & $\begin{array}{c}2 \\
(20 \%)\end{array}$ & $\begin{array}{c}1 \\
(10 \%)\end{array}$ & $\begin{array}{c}2 \\
(20 \%)\end{array}$ & $\begin{array}{c}2 \\
(20 \%)\end{array}$ & $1(10 \%)$ & $\begin{array}{c}10 \\
(100 \%)\end{array}$ \\
\hline
\end{tabular}




\begin{tabular}{ccccccccc}
\hline \multirow{2}{*}{20} & $1(5,9 \%)$ & 2 & $2(11,8 \%)$ & 7 & 2 & $3(17,6 \%)$ & 0 & 17 \\
& & $(11,8 \%)$ & & $(41,2 \%)$ & $(11,8 \%)$ & & $(0 \%)$ & $(100 \%)$ \\
\hline \multirow{2}{*}{21} & 0 & 0 & 2 & 2 & 2 & 2 & $2(20 \%)$ & 10 \\
& $(0 \%)$ & $(0 \%)$ & $(20 \%)$ & $(20 \%)$ & $(20 \%)$ & $(20 \%)$ & $(100 \%)$ \\
\hline \multirow{2}{*}{22} & 0 & 0 & 0 & 0 & 0 & $1(100 \%)$ & 0 & $1(100 \%)$ \\
& $(0 \%)$ & $(0 \%)$ & $(0 \%)$ & $(0 \%)$ & $(0 \%)$ & & $(0 \%)$ & \\
\hline
\end{tabular}

Hasil distribusi frekuensi Digit Span Test Forward dan Backward berdasarkan jenis kelamin ditunjukkan oleh tabel 6 dan 7 berikut.

Tabel 6 Distribusi Frekuensi Digit Span Test Forward Berdasarkan jenis kelamin Responden

\begin{tabular}{ccccccccc}
\hline Jenis & \multicolumn{7}{c}{ Skor Digit Span Test Forward } & \multirow{2}{*}{ Total } \\
\cline { 2 - 9 } Kelamin & 3 & 4 & 5 & 6 & 7 & 8 & 9 & \\
\hline \multirow{2}{*}{ Laki-laki } & $0(0 \%)$ & 1 & 1 & 1 & 1 & 1 & 4 & $9(100 \%)$ \\
& & $(11,1 \%)$ & $(11,1 \%)$ & $(11,1 \%)$ & $(11,1 \%)$ & $(11,1 \%)$ & $(44,4 \%)$ & \\
\hline \multirow{2}{*}{ Perempuan } & $0(0 \%)$ & $1(3,4 \%)$ & 4 & 4 & 11 & 8 & $1(3,4 \%)$ & 29 \\
& & & $(13,8 \%)$ & $(13,8 \%)$ & $(37,9 \%)$ & $(27,6 \%)$ & & $(100 \%)$ \\
\hline
\end{tabular}

Tabel 6 menunjukkan dari total 9 orang responden yang berjenis kelamin laki-laki paling banyak memperoleh skor 9 yaitu sebesar 44,4\%; masing-masing skor 4, 5, 6, 7, dan 8 diperoleh oleh 11,1\% responden; dan tidak ada yang memperoleh skor 3. Sedangkan untuk yang berjenis kelamin perempuan, dari 29 responden didapatkan sebanyak 37,9\% memperoleh skor 7; 27,6\% memperoleh skor 8; masing- masing 13,8\% memperoleh skor 5 dan $6 ; 3,4 \%$ masing-masing untuk skor 4 dan 9, dan tidak ada yang memperoleh skor 3 .

\section{Tabel 7 Distribusi Frekuensi Digit Span Test Backward} Berdasarkan jenis kelamin Responden

\begin{tabular}{lcccccccc}
\hline Jenis & \multicolumn{7}{c}{ Skor Digit Span Test Backward } & \multirow{2}{*}{ Total } \\
\cline { 2 - 7 } Kelamin & 2 & 3 & 4 & 5 & 6 & 7 & 8 & $9(100 \%)$ \\
\multirow{2}{*}{ Laki-laki } & 0 & 0 & 1 & 3 & 2 & 1 & 2 & 9 \\
& $(0 \%)$ & $(0 \%)$ & $(11,1 \%)$ & $(33,3 \%)$ & $(22,2 \%)$ & $(11,1 \%)$ & $(22,2 \%)$ & \\
\hline \multirow{2}{*}{ Perempuan } & $1(3,4 \%)$ & 4 & 5 & 7 & 4 & 7 & $1(3,4 \%)$ & 29 \\
& & $(13,8 \%)$ & $(17,2 \%)$ & $(24,1 \%)$ & $(13,8 \%)$ & $(24,1 \%)$ & $(100 \%)$ \\
\hline
\end{tabular}

Tabel 7 menunjukkan dari total 9 orang responden yang berjenis kelamin laki-laki paling banyak memperoleh skor 5 yaitu sebesar 33,3\%; masing-masing skor 6 , dan 8 diperoleh oleh $22,2 \%$ responden; $11,1 \%$ responden memperoleh masing-masing skor 4 dan 7; dan tidak ada yang memperoleh skor 2 dan 3. Sedangkan untuk yang berjenis kelamin perempuan, dari 29 responden didapatkan sebanyak masing-masing 24,1\% memperoleh skor 5 dan 7; sebanyak 17,2\% memperoleh skor 4; 13,8\% masing-masing memperoleh skor 3 dan 6; dan 3,4\% masing-masing untuk skor 2 dan 8 . 


\section{PEMBAHASAN}

Sampel dalam penelitian ini adalah mahasiswa Program Studi Kedokteran Universitas Malikussaleh Tahun Ajaran 2018/2019 yang memenuhi kriteria inklusi dan eksklusi. Responden yang berpartisipasi dalam penelitian ini awalnya berjumlah 43 orang, akan tetapi yang memenuhi kriteria inklusi dan eksklusi hanya sebanyak 38 orang. Sampel yang diambil hanya satu angkatan dengan maksud meminimalisasi perbedaan tingkat pengetahuan yang dimiliki oleh responden, yang akan mempengaruhi kognitif responden.

Adapun karakteristik responden yang dinilai pada penelitian ini adalah usia dan jenis kelamin. Usia responden pada penelitian ini berada pada rentang usia 19 sampai 22 tahun dengan distribusi frekuensi yang terbanyak adalah usia 20 tahun yaitu sebanyak 18 orang (44,74\%). Usia 19 dan 21 tahun memiliki distribusi frekuensi yang sama yaitu 10 orang $(26,32 \%)$, dan hanya 1 orang $(2,63 \%)$ yang berusia 22 tahun. Jenis kelamin dengan distribusi frekuensi terbanyak adalah perempuan yaitu 29 orang (76,32\%), sedangkan laki-laki hanya 9 orang $(23,68 \%)$.

Tingkat konsentrasi responden pada penelitian ini dinilai dengan menggunakan Digit Span Test Forward dan Backward. Digit Span Test Forward lebih dimaksudkan untuk menilai konsentrasi yang berkaitan dengan memori jangka pendek sedangkan Digit Span Test Backward lebih dimaksudkan untuk menilai konsentrasi yang berkaitan dengan memori kerja. Digit span forward hanya memerlukan proses registrasi awal dari informasi verbal dan passive holding dari informasi tersebut untuk kepentingan repetisi segera; sedangkan digit span backward memerlukan manipulasi aktif dari informasi setelah registrasi awal untuk memformulasikan suatu respon sebelum melakukan respon tersebut (active manipulation task). Memori kerja diatur terutama di lobus frontal sedangkan memori jangka pendek diproses lebih ke posterior (di korteks parietal inferior kiri, umumnya di area girus angular dan supramarginal inferior). ${ }^{6}$

Hasil tes Digit Span Forward menunjukkan bahwa skor yang paling banyak diperoleh responden adalah skor 7 yaitu sebanyak 31,58\% dengan rerata yang didapatkan adalah 6,95 \pm 1,39 dan skor median adalah 7; sedangkan untuk digit span backward skor terbanyak adalah 5 yaitu $26,32 \%$ dengan rerata 5,37 $\pm 1,57$ dan skor median adalah 5 . Adapun rangkaian angka terpanjang yang dapat diulangi dengan benar oleh semua responden adalah 4 digit untuk digit span forward dan 2 digit untuk digit span backward. Hasil ini tidak jauh berbeda dengan penelitian yang dilakukan oleh Monaco et al. (2013) terhadap 362 sampel orang italia sehat, 
dimana didapatkan hasil rerata skor untuk digit span forward pada golongan usia 20-30 tahun

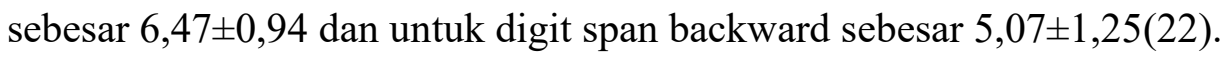

Hasil digit span forward dan backward menunjukkan sebagian besar responden memperoleh skor di atas atau sama dengan skor median yaitu $68,42 \%$ untuk forward dan $71,05 \%$ untuk backward. Hasil ini menunjukkan bahwa tingkat konsentrasi mahasiswa Program Studi Kedokteran Universitas Malikussaleh pada saat dilakukan penelitian cukup baik.

Jika ditinjau dari faktor usia, sebaran skor untuk tiap usia pada digit span forward terlihat memiliki pola yang hampir sama, dimana skor terbanyak yang diperoleh adalah 7 (kecuali untuk usia 22 tahun karena hanya 1 orang responden). Pada digit span backward pola yang terlihat juga hampir sama, dimana tidak dijumpai puncak atau skor terbanyak untuk setiap usia. Secara umum tingkat konsentrasi untuk setiap usia juga cukup baik, dimana sebaran sebagian besar responden berada di atas atau sama dengan skor median masingmasing.

Usia sangat berpengaruh pada tingkat konsentrasi seseorang. Menurut Aini konsentrasi merupakan hal yang harus dilatih dan dimiliki sejak usia kanak-kanak. Seseorang yang terbiasa dilatih berkonsentrasi sejak dini akan sangat berpengaruh pada kehidupan masa depannya. Pada tahap usia remaja, seseorang cenderung lebih mengikuti kebiasaan dan perilaku temannya. Oleh karena itu, dapat disimpulkan bahwa usia sangat berpengaruh pada tingkat konsentrasi seseorang, terutama pada saat usia remaja. Pada usia remaja seseorang cenderung mengikuti perilaku dan kebiasaan dari teman sebayanya atau teman dekatnya. Apabila temannya memiliki sikap dan konsentrasi yang baik, maka akan berpengaruh pula pada individu tersebut. Begitupun sebaliknya, apabila teman dekatnya memilki sikap dan konsentrasi yang buruk maka individu tersebut juga akan memilki sikap dan konsentrasi yang buruk juga. Konsentrasi belajar dipengaruhi oleh dua faktor, yaitu faktor internal dan faktor eksternal. Faktor internal merupakan faktor yang berasal dari dalam diri seseorang berupa kurangnya minat belajar dan buruknya kondisi kesehatan. ${ }^{7}$ Hasil penelitian Justian (2012) menyatakan bahwa kurangnya minat terhadap pelajaran, keadaan lingkungan yang tidak kondusif, pikiran kacau, masalah kesehatan dan kebosanan juga dapat mempengaruhi konsentrasi belajar. ${ }^{8}$ Konsentrasi yang baik akan tercapai apabila seseorang memiliki minat atau motivasi yang tinggi, menjaga kesehatan dan keadaan lingkungan yang kondusif. Adanya konsentrasi pada saat belajar akan membuat seseorang merasa senang mengikuti proses pembelajaran sehingga materi yang diterima akan mudah untuk di pahami. Seseorang yang memiliki konsentrasi belajar yang baik tidak akan mudah mengalihkan perhatiannya 
pada hal lain yang tidak ada hubungannya dengan hal tersebut. Seseorang dengan konsentrasi belajar yang baik akan memperoleh hasil yang maksimal dan baik buruknya prestasi yang dicapai seseorang juga dipengaruhi oleh konsentrasi belajarnya. ${ }^{9}$

Perbandingan distribusi frekuensi skor digit span forward antara jenis kelamin lakilaki dan perempuan yang ditunjukkan oleh tabel 4.6 dan 4.7, memperlihatkan bahwa pada laki-laki seakan cenderung memiliki skor digit span forward lebih baik dibandingkan perempuan, dimana skor terbanyak yang diperoleh oleh laki-laki adalah 9 (44,4\%), sedangkan perempuan 7 (37,9\%). Akan tetapi jika ditinjau dari jumlah responden yang memiliki skor diatas atau sama dengan skor median (yaitu 7), terlihat keduanya tidak jauh berbeda, dimana laki-laki sebesar 66,6\% dan perempuan 68,9\%. Tidak demikian dengan hasil digit span backward, dimana didapatkan laki-laki lebih banyak memperoleh skor diatas atau sama dengan skor median (yaitu 5) sebesar 98,9\%, dibandingkan dengan perempuan yang hanya sebesar $65,6 \%$.

Penelitian serupa yang dilakukan Gregoire \& Van der Linden (1997) menggunakan Digit Span test Forward maupun Backward menunjukkan adanya hubungan peningkatan usia dengan penurunan hasil test digit span, penurunan ini terjadi perlahan dan mulai terjadi pada usia diatas 65 tahun; akan tetapi tidak ada perbedaan signifikan antara jenis kelamin laki-laki dan perempuan. ${ }^{10}$ Penelitian lain oleh Monaco et al (2013) terhadap sekelompok besar sampel individu sehat yang dianalisis variabel sosio-demografi berupa usia, jenis kelamin dan pendidikan menyimpulkan bahwa peningkatan usia berkaitan dengan penurunan progresif skor digit span test, semakin tinggi pendidikan berkaitan dengan peningkatan skor digit span test, dan tidak ada pengaruh yang signifikan antara jenis kelamin dan skor digit span test. ${ }^{5}$

\section{KESIMPULAN}

1. Rentang usia responden yang berpartisipasi pada penelitian ini antara 19-22 tahun dengan persentase terbanyak usia 20 tahun (44,74\%), dan sebagian besar responden adalah perempuan $(76,32 \%)$.

2. Tingkat konsentrasi mahasiswa Program Studi Kedokteran Universitas Malikussaleh yang dinilai menggunakan Digit Span Test menunjukkan nilai yang baik dimana distribusi frekuensi sebagian besar responden berada di atas atau sama dengan nilai median (skor 7 untuk digit span forward dan 5 untuk backward) baik untuk digit span forward $(68,42 \%)$ maupun backward (71,05\%). 


\section{REFERENSI}

1. Sörqvist P, Marsh JE. How concentration shields against distraction. Curr. Dir.Psychol.Sci. 2015; 24: 267-272. doi:10.1177/0963721415577356

2. Smid HG, de Witte MR,Homminga I, van den Bosch RJ. Sustained and transient attention in the continuous performance task. J Clin Exp Neuropsychol. 2006(6):859-83

3. Dalton P, Santangelo V, Spence C. The role of working memory in auditory selective attention. Q J Exp Psychol 2009(62):2126-2132. doi:10.1080/17470210903023646

4. Sorqvist P, Dahlstrom O, Karlsson T, Ronnberg J. Concentration: The neural underpinnings of how cognitive load shields against distraction. Front. Hum. Neurosci. 2016(10):221. doi: 10.3389/fnhum.2016.00221

5. Monaco M, Costa A, Caltagirone C. Forward and Backward Span for Verbal and visuospatial data: standardization and normative data from an Italian adult population. Neuro.Sci 2013 (34):749-754

6. Prifitera A, Saklofske DH,Weiss LG. WISC-IV Clinical Use and Interpretation: Scientist-Pratitioner Perspectives. New York. Elsevier. 2011

7. Olivia F. Mendampingi Anak Belajar: Bebaskan Anak Dari Stres dan Depresi Belajar. Jakarta: PT Elex Media Komputindo. 2010

8. Ikawati, M.P.D. Upaya Meningkatkan Konsentrasi Belajar Siswa KMS (Kartu Menuju Sejahtera) Menggunakan Konseling Kelompok bagi Siswa. Psikopedagogia, Vol. 5, No.1, 2016

9. Slameto. Belajar dan Faktor-Faktor yang Mempengaruhi Cetakan Keenam. Jakarta: PT Rineka Cipta. 2013

10. Gregoire J, van der Linden M. Effect of Age on Forward and Backward Digit Spans. Aging, Neuropsychology and Cognition. 1997 (4):2 pp 140-149 